\title{
Hydrogeological Model of Latvia After Increasing Density of its Hydrographical Network
}

\author{
Aivars Spalvins ${ }^{1}$, Janis Slangens ${ }^{2}$, Inta Lace ${ }^{3}$, Olgerts Aleksans ${ }^{4}$, \\ Kaspars Krauklis ${ }^{5}$, Viesturs Skibelis ${ }^{6}$, Irina Eglite, \\ ${ }^{1-7}$ Riga Technical University
}

\begin{abstract}
In 2010 - 2012 the hydrogeological model (HM) of Latvia was developed and was named LAMO by scientists of Riga Technical University (RTU). The model comprises geological and hydrogeological information accumulated by the Latvian Environment, Geology and Meteorology Center (LEGMC). LAMO simulates the active groundwater zone that provides drinking water. To ensure compatibility with models of other countries, the worldwide used commercial program Groundwater Vistas $(\mathrm{GV})$ is applied for running LAMO. In 2013 - 2014 LAMO was considerably upgraded and since 2012 three versions (LAMO1, LAMO2, LAMO3) of the HM have been developed. Density of the hydrogeological network was increased, transmissivity distributions for aquifers were refined and special software tools were developed to join the elements of hydrographical network (rivers, lakes, sea) with the HM body. In the paper the main innovations that have converted the LAMO2 into the next LAMO3 version are considered.
\end{abstract}

Keywords - Hydrogeological model, hydrographical network, transmissivity of aquifers.

\section{INTRODUCTION}

The European Union (EU) countries are developing HM where by means of computer modeling the information necessary for groundwater management is obtained to implement the aims laid down by the EU Water Framework Directive [1] for sustainable use of water resources. In Latvia, the LEGMC team prepares plans for surface and groundwater management of four cross-border river basin districts: those of the Venta, Lielupe, Daugava and Gauja rivers. In 2010 - 2012 the HM LAMO was established by the scientists of RTU. The commercial program Groundwater Vistas $(\mathrm{GV})$ was used for running LAMO [2]. The SURFER [3] and EXCEL [4] programs were applied to prepare the initial data for the GV system and to present the obtained results. In publications [5][9] novel methods and tools, used to establish LAMO, are considered.

In 2013 scientists of RTU using the results of LAMO prepared five reports [10]-[14] which were used by specialists of LEGMC for improving the management of groundwater bodies in the above mentioned four river basin districts of Latvia. The main items of the RTU reports are summarized in [15].

In 2013 - 2014 LAMO was considerably updated [16], [17] and due to the innovations four successive versions of LAMO can be distinguished. The comparison of LAMO versions is presented in the Appendix, Table IA. In 2012 the first version, LAMO1, was established and the report [10] revealed the necessity for urgent improvements of the HM. In the first half of 2013 the following two upgrades were accomplished which converted LAMO1 into the LAMO2 version:

1. To avert unrealistic groundwater head distribution (shown for the profile $2 \mathrm{~W}-2 \mathrm{C}$ in [10]), within the 24-th thick united aquifer D2ar\#, the one was split into its natural parts: the aquifers D2brt, D2ar and the aquitard D2arz (Fig. 1) and the number of LAMO planes increased from 25 to 27 ;

2. River valleys were fully implemented into the HM body; for LAMO1 the valleys were immersed only into the Quaternary strata.

LAMO2 results were used to prepare the reports [11]-[14].

In 2014 LAMO 2 was turned into the LAMO3 version, due to the following upgrades:

1. The density of the hydrographical network of HM was increased (the number of rivers and lakes was changed from 199 to 469 and from 67 to 127 , accordingly);

2. The transmissivity distribution for primary aquifers of HM were considerably refined [16];

3. To prepare the data for the hydrographical network special software was developed [17].

In 2014 the next LAMO4 version will appear because the following improvements of LAMO3 will be carried out:

1. The plane approximation step will be decreased from 500 meters to 250 meters;

2. To join the rivers of HM with its body more accurately, the measured flow of rivers will be accounted for;

In the paper the versions of LAMO2 and LAMO3 are compared. Due to considerable amount of complex maps and tables these materials are assembled in the Appendix.

\section{INCREASED DENSITY OF THE HM HYDROGRAPHICAL NETWORK}

In Fig. 1a the "old" hydrographical network of LAMO2 and the "new" rivers and lakes included in the LAMO3 are shown. Evidently, in the LAMO3 the set of 469 rivers covers the land of Latvia much more evenly than the 199 rivers of the LAMO2. In LAMO3 sixty small lakes were added.

Hence the new rivers and lakes of LAMO3 are located mostly in the aquifer $\mathrm{Q} 2$, the groundwater flow regime of the $Q$-system changed considerably (Appendix, Table IIA):

- local inflow increased from 3313 thous. $m^{3} /$ day to 7270 thous. $\mathrm{m}^{3} /$ day;

- the flow of rivers increased from 5680 thous. $\mathrm{m}^{3} / \mathrm{day}$ to 9436 thous. $\mathrm{m}^{3} /$ day; 
- the outflow through the ground surface decreased from 3775 thous. $\mathrm{m}^{3} /$ day to 1804 thous. $\mathrm{m}^{3} /$ day;

- the flow of lakes slightly increased from 426 thous. $\mathrm{m}^{3} /$ day to 487 thous.m ${ }^{3} /$ day;

- the outflow through the border decreased from 136 thous. $\mathrm{m}^{3} /$ day to 100 thous. $\mathrm{m}^{3} /$ day.

The outflow through the ground surface was partly reduced by minimizing (by 20 times) links of rivers and lakes with the relh plane of HM (Fig. 1). The links of lakes with the HM body were decreased by 500 times. The links of rivers with the HM body were only slightly adjusted in comparison with the ones of the LAMO2 version. The influence of the $m=0$ areas of aquitards, thickness of which is $\varepsilon=0.02$ meter, was decreased by 10 times (for the D3akz and D3elz aquitards by 100 times) by increasing their conductivity.

The total infiltration slightly increased from 11194 thous. $\mathrm{m}^{3} /$ day to 12763 thous. $\mathrm{m}^{3} /$ day which was very close to the value of 13000 thous. $\mathrm{m}^{3} /$ day given in [18].

For the LAMO3, due to increased intensity of groundwater processes for the $Q$-system, processes in the primary strata became slower. In Fig. 2A the distribution of groundwater flow and heads are shown for the primary aquifers of the LAMO2 and LAMO3 versions. Evidently, the LAMO3 discharge flow is smaller than the one of the LAMO2 version, but the head isoline pattern is similar in both versions. One can draw identical conclusions when observing Fig. 3a, where flow and heads of the D2ar aquifer of the LAMO2 and LAMO3 version are compared. In Fig. $2 \mathrm{a}$ and Fig. 3a simple color scales were applied, in order to distinguish the areas of discharge, transit and recharge flow. In Fig. 4a the LAMO3 infiltration flow for the primary and D2ar aquifers are shown where the full color scale for the infiltration flow was used.

In Fig. 5a the geological profile $4 \mathrm{~W}-4 \mathrm{E}$ is shown for the LAMO2 and LAMO3 versions. For both HM versions the head isolines were drawn and one can conclude from comparing these profiles that the heads of the LAMO3 version are slightly lower $(5-10$ meters) than in the LAMO2. For the profile of LAMO3 the infiltration flow distribution picture was applied. In [8] the methods of creating profiles for the head and flow distributions ( $\varphi$ and $q$-maps) are explained. The isolines of heads and flow must be vertical, within aquifers and aquitards, accordingly. In Fig. 5a the SURFER color mode was used to show the flow distribution. The profile flow $q$-map assembles information (geological stratification, distributions of infiltration flows) carried by the vertical incision of the HM body. For example, the preQ and D2ar maps in Fig. 4a provide data, accordingly, for the top surface and the D3arz aquitard of the Fig. 5a profile. The flow profiles helped to find out and to correct some errors of HM, especially the ones related to joining rivers with the LAMO3 body.

\section{COMPARISON OF GROUNDWATER FLOW BALANCE OF THE LAMO2 AND LAMO3 VERSIONS}

For the LAMO2 and LAMO3 version the flow balance of Latvia is presented in the Appendix, Table IIA. The scheme in Fig. 6a provides the graphical interpretation for the LAMO3 flow balance difference for Latvia between LAMO2 and LAMO3 version is given and the scheme in Fig. 7a explains

\begin{tabular}{|c|c|c|c|}
\hline $\begin{array}{l}\text { No of } \\
\text { HM } \\
\text { plane }\end{array}$ & Name of layer & $\begin{array}{l}\text { Geolo- } \\
\text { gical } \\
\text { code }\end{array}$ & $\begin{array}{l}\text { HM } \\
\text { plane } \\
\text { code }\end{array}$ \\
\hline 1. & Relief & relh & relh \\
\hline 2. & Aeration zone & aer & aer \\
\hline 3. & $\begin{array}{l}\text { Unconfined } \\
\text { Quaternary }\end{array}$ & Q4-3 & Q2 \\
\hline 4. & Upper moraine & $\mathrm{gQ3}$ & $\mathrm{gQ} 2 \mathrm{z}$ \\
\hline 5. & $\begin{array}{l}\text { Confined } \\
\text { Quaternary or } \\
\text { Jura }\end{array}$ & $\begin{array}{l}\text { Q1-3 } \\
\text { J }\end{array}$ & Q1\# \\
\hline 6. & $\begin{array}{l}\text { Lower moraine } \\
\text { or Triass }\end{array}$ & $\begin{array}{l}\mathrm{gQ1-3} \\
\mathrm{T}\end{array}$ & gQ1\#z \\
\hline 7. & $\begin{array}{l}\text { Perma } \\
\text { Karbons } \\
\text { Skerveles } \\
\text { Ketleru }\end{array}$ & $\begin{array}{l}\text { P2 } \\
\text { C1 } \\
\text { D3šk } \\
\text { D3ktl }\end{array}$ & D3ktI\# \\
\hline 8. & Ketleru & D3ktl & D3ktlz \\
\hline 9. & $\begin{array}{l}\text { Zagares } \\
\text { Svetes } \\
\text { Tervetes } \\
\text { Muru }\end{array}$ & $\begin{array}{l}\text { D3žg } \\
\text { D3sv } \\
\text { D3tr } \\
\text { D3mr }\end{array}$ & D3zg\# \\
\hline 10. & Akmenes & D3ak & D3akz \\
\hline 11. & $\begin{array}{l}\text { Akmenes } \\
\text { Kursas } \\
\text { Jonisku }\end{array}$ & $\begin{array}{l}\text { D3ak } \\
\text { D3krs } \\
\text { D3jn }\end{array}$ & D3krs\# \\
\hline 12. & $\begin{array}{l}\text { Elejas } \\
\text { Amulas }\end{array}$ & $\begin{array}{l}\text { D3el } \\
\text { D3aml }\end{array}$ & D3el\#z \\
\hline 13. & $\begin{array}{l}\text { Stipinu } \\
\text { Katlesu } \\
\text { Ogres } \\
\text { Daugavas }\end{array}$ & $\begin{array}{l}\text { D3stp } \\
\text { D3ktl } \\
\text { D3og } \\
\text { D3dg }\end{array}$ & D3dg\# \\
\hline 14. & $\begin{array}{l}\text { Daugavas } \\
\text { Salaspils }\end{array}$ & $\begin{array}{l}\text { D3dg } \\
\text { D3slp }\end{array}$ & D3slp\#z \\
\hline 15. & Plavinu & D3pl & D3pl \\
\hline 16. & $\begin{array}{l}\text { Plavinu } \\
\text { Amatas }\end{array}$ & $\begin{array}{l}\text { D3pl } \\
\text { D3am }\end{array}$ & D3am\#z \\
\hline 17. & Amatas & D3am & D3am \\
\hline 18. & Upper Gauja & D3gj2 & D3gj2z \\
\hline 19. & Upper Gauja & D3gj2 & $\mathrm{D} 3 \mathrm{gj} 2$ \\
\hline 20. & Lower Gauja & D3gj1 & D3gj1z \\
\hline 21. & Lower Gauja & D3gj1 & D3gj1 \\
\hline 22. & Burtnieku & D2brt & D2brtz \\
\hline 23. & Burtnieku & D2brt & D2brt \\
\hline 24. & Arikula & D2ar & D2arz \\
\hline 25. & Arikula & D2ar & D2ar \\
\hline 26. & $\begin{array}{l}\text { Narvas } \\
\text { Narvas }\end{array}$ & $\begin{array}{l}\mathrm{D} 2 \mathrm{nr} 2 \\
\mathrm{D} 2 \mathrm{nr} 1 \\
\end{array}$ & D2nr\#z \\
\hline 27. & Pernavas & D2prn & $\mathrm{D} 2 \mathrm{pr}$ \\
\hline
\end{tabular}

Fig. 1. Vertical schematization of LAMO. 
graphically the Table IIIA of the Appendix. To compare the flow balance for Latvia of LAMO2 and LAMO2 version, the

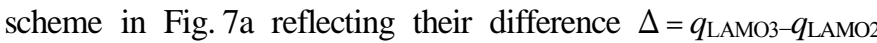
must be considered. The total local increase of LAMO3 is 3564 thous. $\mathrm{m}^{3} /$ day. It comprises four components (3 756 for rivers, 171 for lakes, 37 for wells, -400 for border). The well flow increase is formal, because in the D3pl aquifer the drainage system rate 37 thous. $\mathrm{m}^{3} /$ day of the Riga HPS is added. The border flow decrease is considerable $(936 \rightarrow 536)$. The increase for the river flow for LAMO3 is caused mainly by the new rivers of the $Q-$ system $(3295 \rightarrow 6627)$. It is possible that for the next LAMO4 version the river flow should be decreased.

The considerable increase of the lake flow for the primary strata $(2 \rightarrow 112)$ can be explained as follows:

- water reservoirs of the Riga, Kegums and Plavinu HPS are treated as lakes;

- $\quad$ some lakes are fully or partly linked with the primary aquifers D3zg\#, D3gj1, D2brt.

In Appendix, Table IVA the relative difference $\delta=100 \Delta /$ $q_{\text {LAMO2 }}$ between the local balance of LAMO2 and LAMO3 is presented in the Appendix, Table IIIA and Table IIA (LAMO2). The relative difference enables to ascertain changes of groundwater flow if compared with the LAMO2 flow. In the Appendix, Table IVA its content may be much larger than $100 \%$. For example, for the lake the relative difference is $\infty$ if no lake is linked with the LAMO2 aquifer $\left(q_{\text {LAMO2 }}=0\right)$.

When considering the local balance of the D3gj1, D2brt and D2ar aquifers one can notice that their local inflow has decreased. For this reason the river and border flow there also is smaller. This decrease may be partly caused by nearly twofold reduced permeabilities of these aquifers (Table I) for the LAMO3 version.

\section{REFINEMENT OF TRANSMISSIVITY DISTRIBUTION OF AQUIFERS}

For the GV-system the transmissivity of aquifers is controlled by changing the permeability $k$-maps. The $k$-map represents the product:

$$
k=k_{\text {norm }} k_{\text {mean }}, \quad k_{\text {norm }}=k / k_{\text {mean }}
$$

where $k_{\text {norm }}$ and $k_{\text {mean }}$ are accordingly normalized and denote permeabilities of a geological stratum.

It is explained in [15] how the data of well pumping were used to obtain $k$-maps for the LAMO3 version. Table I summarizes the results of this investigation:

- for LAMO2 $k_{\text {norm }}=1$, because constant values of $k$ are applied;

- $\quad$ for LAMO3 $k_{\text {norm }}$ is variable and this feature partly causes considerable changes of the HM groundwater flow balance.

To calibrate HM, "theoretical" value $k_{\text {meant }}$ was replaced by $k_{\text {meanc }}>k_{\text {meant }}$, because $k_{\text {meant }}$ corresponded to the minimal transmissivity of an aquifer. It is possible to exploit the well pumping data more punctiliously by accounting for the well partial penetrating factor [15].
TABLE I

COMPARISON OF $K$-MAPS FOR LAMO2 AND LAMO3 VERSION

\begin{tabular}{|l|l|l|l|l|l|}
\hline \multirow{2}{*}{$\begin{array}{l}\text { Aquifer } \\
\text { code }\end{array}$} & \multicolumn{2}{|l|}{ LAMO2 } & \multicolumn{2}{l|}{ LAMO3 } \\
\cline { 2 - 6 } & $k_{\text {norm }}$ & $k_{\text {mean }}$ & $k_{\text {norm }}$ & $k_{\text {meant }} *$ & $k_{\text {meanc }} *$ \\
\hline D3ktl & 1.0 & 3.0 & $0.2-2.1$ & 2.1 & 3.0 \\
\hline D3zg\# & 1.0 & 3.0 & $0.4-2.2$ & 3.6 & 5.0 \\
\hline D3krs\# & 1.0 & 2.0 & $0.4-1.7$ & 5.9 & 6.0 \\
\hline D3dg\# & 1.0 & 10.0 & $0.1-1.2$ & 5.6 & 8.0 \\
\hline D3pl & 1.0 & 10.0 & $0.2-1.9$ & 7.8 & 12.0 \\
\hline D3am & 1.0 & 10.0 & $0.3-1.8$ & 4.7 & 7.0 \\
\hline D3gj2 & 1.0 & 10.0 & $0.4-1.8$ & 5.6 & 8.0 \\
\hline D3gj1 & 1.0 & 14.0 & $0.3-1.9$ & 5.2 & $8 / 0$ \\
\hline D2brt & 1.0 & 5.0 & $0.3-1.8$ & 1.9 & 3.0 \\
\hline D2ar & 1.0 & 5.0 & $0.3-1.9$ & 2.1 & 3.0 \\
\hline
\end{tabular}

$* k_{\text {meant }}, k_{\text {meanc }}$ theoretical and calibrated mean permeability [metre/day] for LAMO3.

\section{CONCLUSION}

In 2014 the LAMO2 version was converted into the more efficient LAMO3 version due to the appliance of denser hydrographical network of HM to the refined aquifer transmissivity distribution and to the use of special software tools. The groundwater flow balance of Latvia for both HM versions differs considerably, especially in the river flow. For the LAMO3 version, the total discharge rate of rivers is larger than the one for the LAMO2 version. The enlargement of the river flow is caused by the increase of the number of rivers simulated by HM. It is possible that the river flow enlargement must be reduced by decreasing the strength of the links that join the rivers with the HM body. More accurate links will be found for the next LAMO4 version when the measured flow in rivers will be accounted for and the HM plane step will be changed from 500 meters to 250 meters.

\section{ACKNOWLEDGMENT}

In 2010-2012 the hydrogeological model of Latvia LAMO was developed within the framework of the project "The Creating of Hydrogeological Model of Latvia to be Used for Management of Groundwater Resources and for Evaluation of Their Recovery Measures." The project has been co-financed by the European Regional Development Fund.

\section{APPENDIX}

Table IA. Comparison of LAMO versions.

Fig. 1a. Hydrogeological network of LAMO2 (blue color) and the new rivers and lakes of LAMO3 (red color).

Fig. 2a. Distribution of groundwater flow and heads for primary preQ aquifers of LAMO2 and LAMO3.

Fig. 3a. Distribution of groundwater flow and heads for D2ar aquifer of LAMO2 and LAMO3.

Fig. 4a. Infiltration flow for primary (preQ) and D2ar aquifers of LAMO3.

Fig. 5a. Geological profile 4W-4E for LAMO2 and LAMO3.

Table IIa. Groundwater flow [thous. $\mathrm{m}^{3} /$ day] balance of LAMO2 and LAMO3 for Latvia (preliminary data).

Table IIIa. Groundwater flow difference [thous. $\mathrm{m}^{3} / \mathrm{day}$ ] balance between LAMO2 and LAMO3 for Latvia (preliminary data).

Table IVa. Groundwater flow relative difference [\%] between local balance of LAMO2 and LAMO3.

Fig. 6a. Scheme of LAMO3 groundwater flow balance of Latvia for Table IIa Fig. 7a. Scheme of LAMO2 and LAMO3 groundwater flow difference balance for Table IIIa 
TABLE IA

COMPARISON OF LAMO VERSIONS

\begin{tabular}{|c|c|c|c|c|c|c|c|c|}
\hline Version & Years & $\begin{array}{c}\text { Grid step } \\
\text { [meter] }\end{array}$ & $\begin{array}{c}\text { Number of } \\
\text { layers }\end{array}$ & $\begin{array}{c}\text { Number of } \\
\text { cells } \times 10^{6}\end{array}$ & $\begin{array}{c}\text { Number of } \\
\text { rivers }\end{array}$ & $\begin{array}{c}\text { Number of } \\
\text { lakes }\end{array}$ & $\begin{array}{c}\text { River } \\
\text { valleys }\end{array}$ & River flow \\
\hline LAMO1 & 2012 & 500 & 25 & 14.25 & 199 & 67 & - & - \\
\hline LAMO1 & 2013 & 500 & 27 & 15.43 & 199 & 67 & + & - \\
\hline LAMO1 & 2014 & 500 & 27 & 15.43 & 469 & 127 & + & - \\
\hline LAMO1 & 2015 & 250 & 27 & 61.56 & 469 & 127 & + & + \\
\hline
\end{tabular}

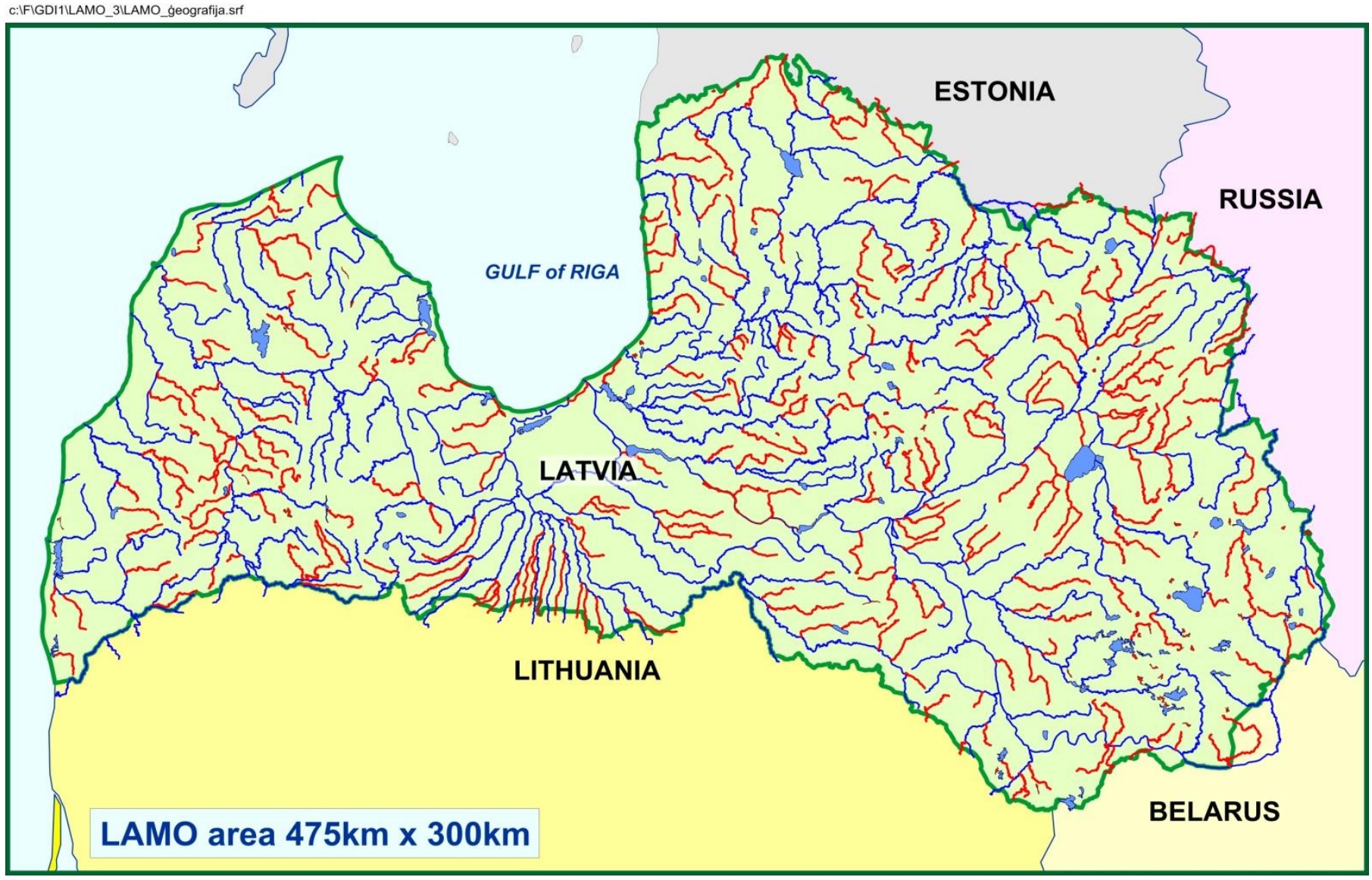

Fig. 1a. Hydrogeological network of LAMO2 (blue color) and the new rivers and lakes of LAMO3 (red color). 
$2014 / 53$

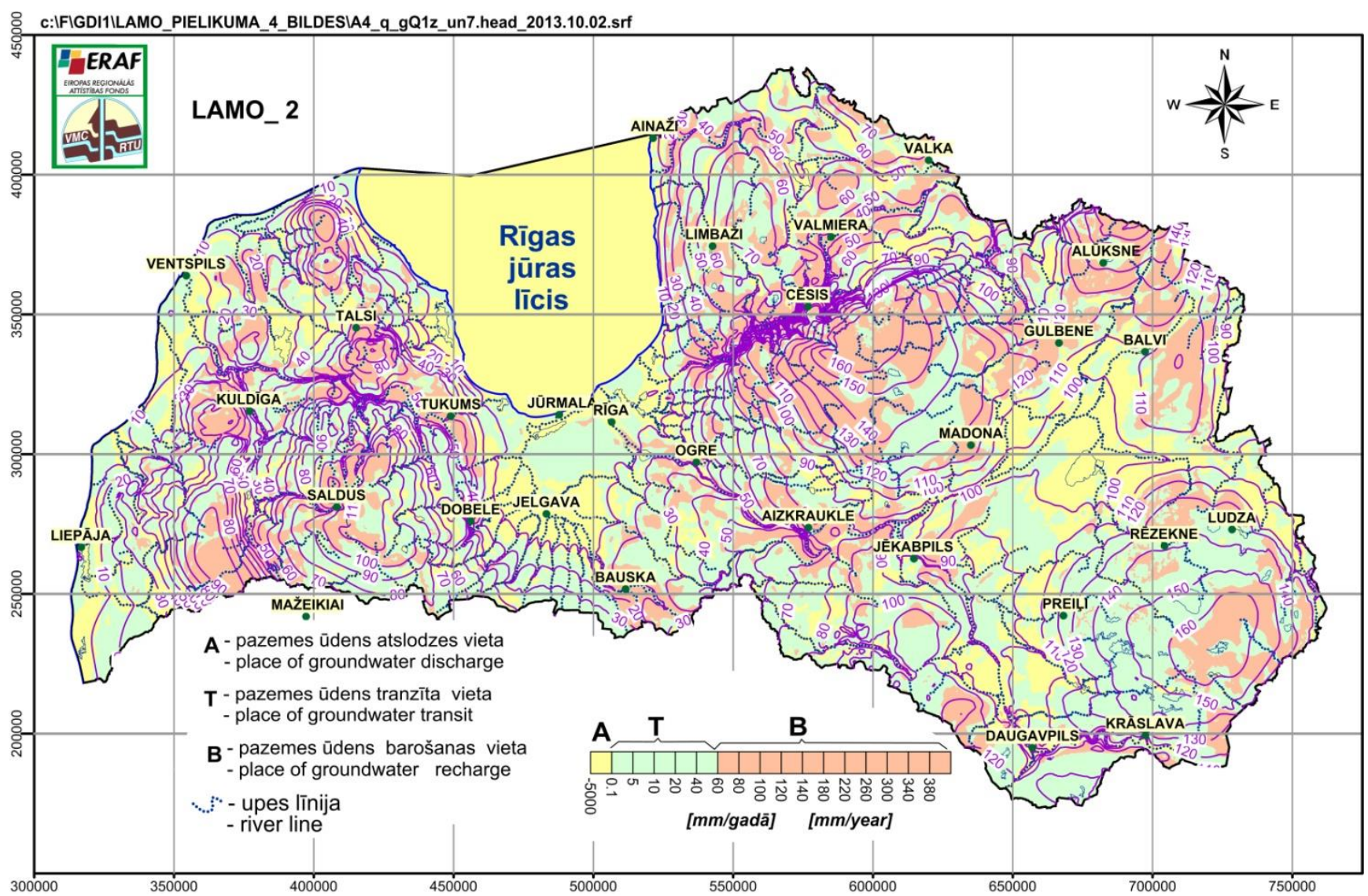

ㅇ c:IFIGDI1LLAMO_3lq_gQ1z_un7.head_2014.okt.srf

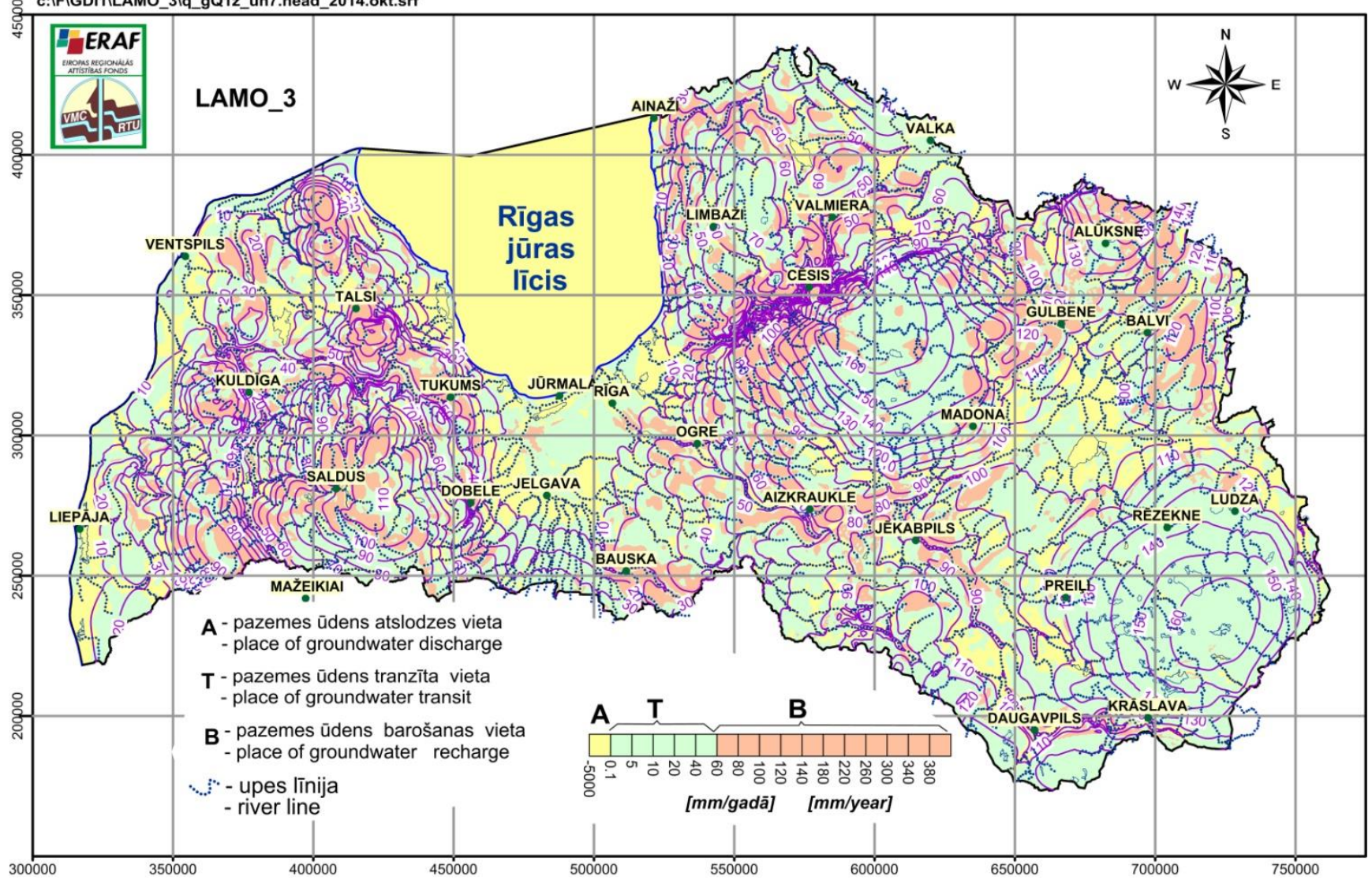

Fig. 2a. Distributions of groundwater flow and heads for primary preQ aquifers of LAMO2 and LAMO3. 

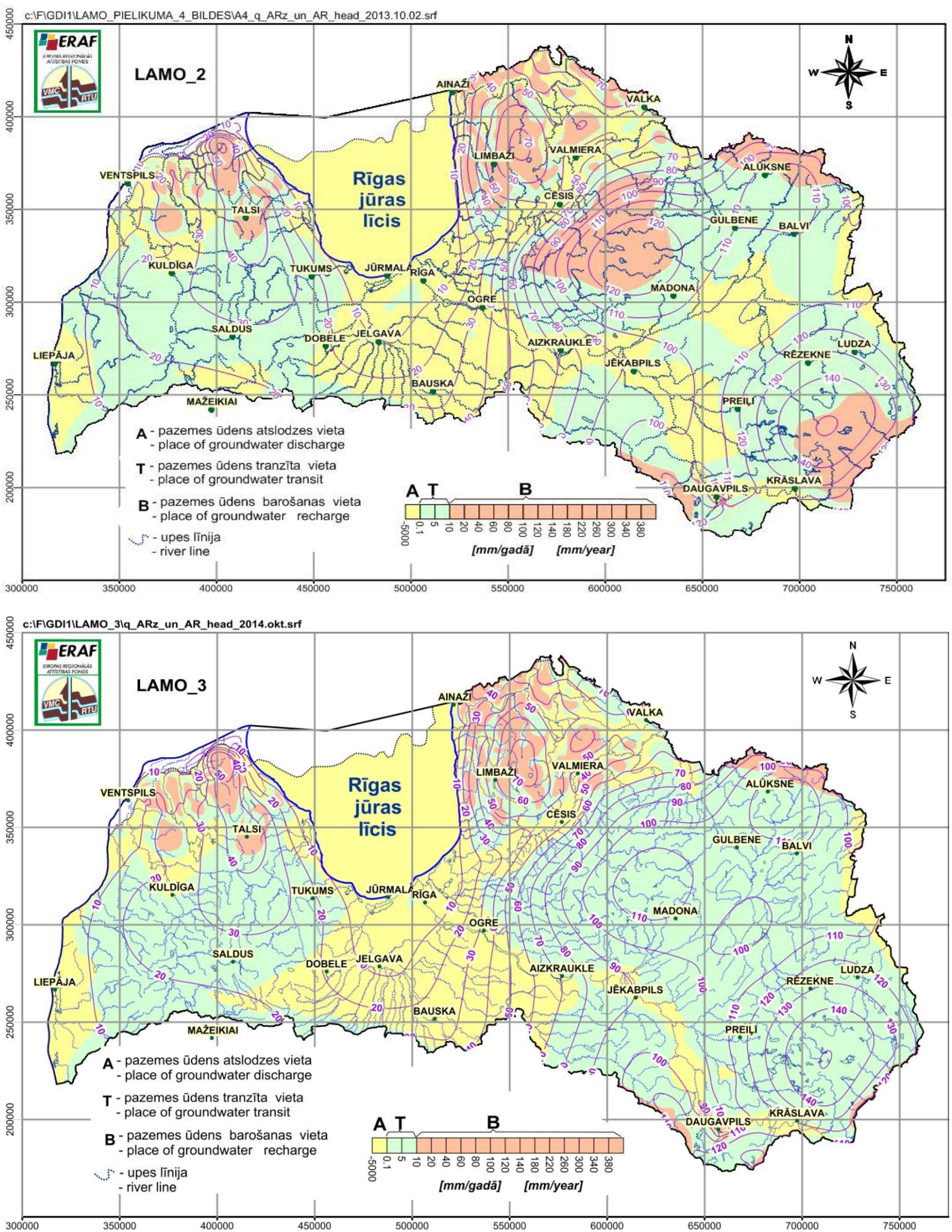

Fig. 3a. Distribution of groundwater flow and heads for D2ar aquifer of LAMO2 and LAMO3. 
$2014 / 53$
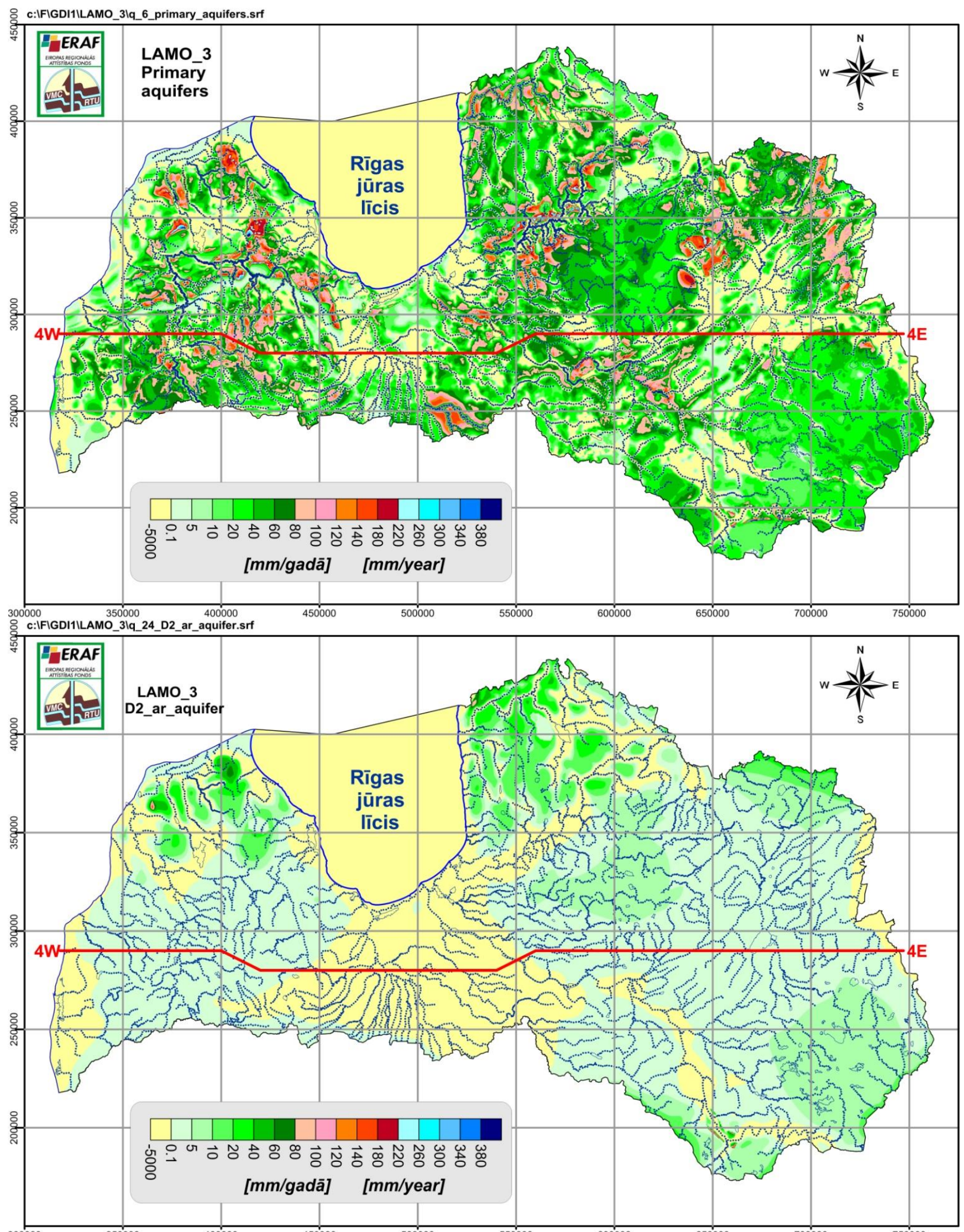

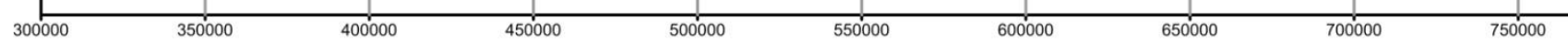

Fig. 4a. Infiltration flow for primary (preQ) and D2ar aquifers of LAMO3. 
\& C:IFIGDI1LAMO_GRIEZUMII4W-4E_2014.10.0614W-4E_LAMO2_OA_S11_2013g.srf
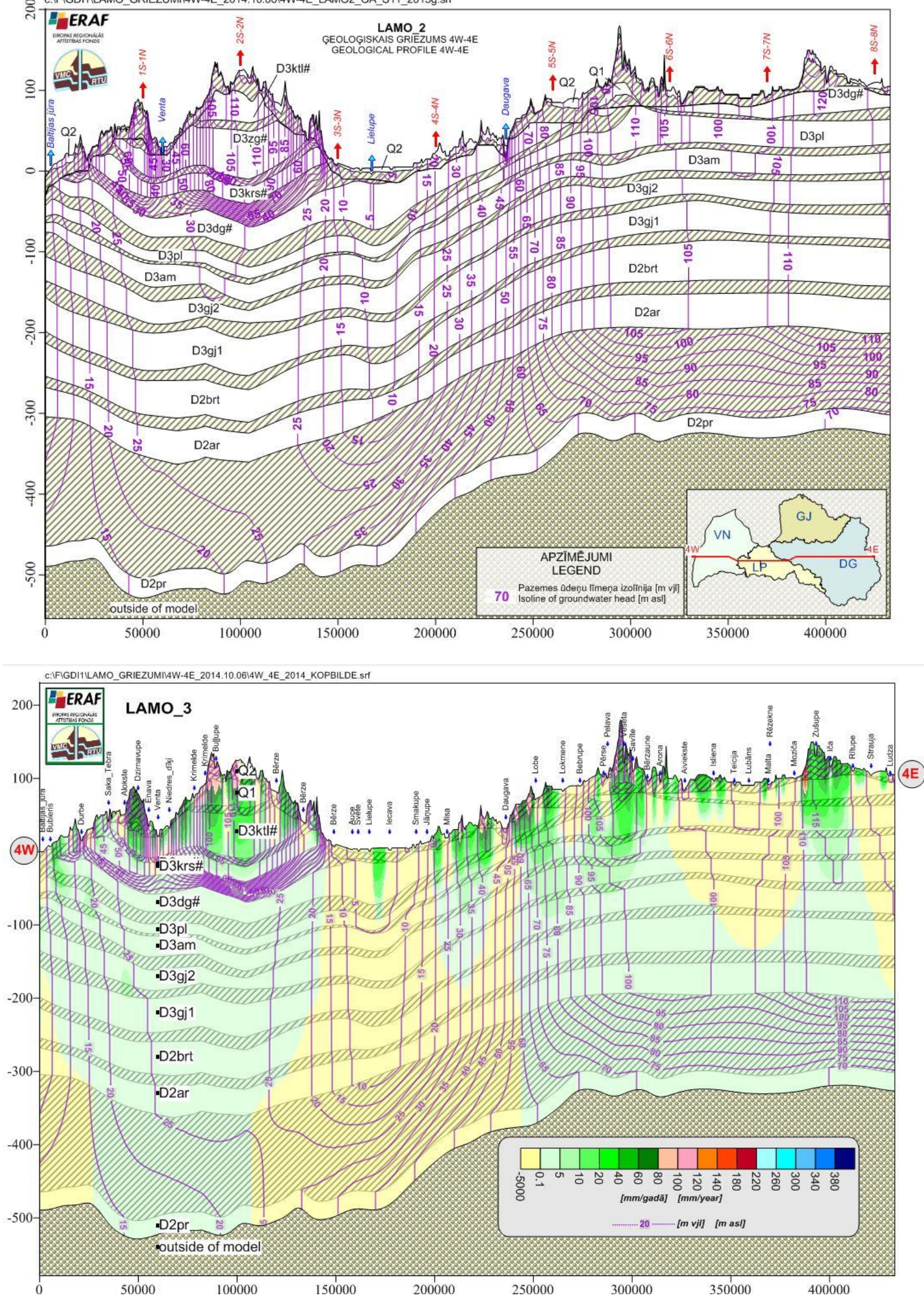

Fig. 5a. Geological profile 4W-4E for LAMO2 and LAMO3. 
TABLE IIA

GROUNDWATER Flow [THOUS.M³/DAY] BALANCE OF LAMO2 AND LAMO3 FOR LATVIA (PRELIMINARY DATA)

LAMO2

\begin{tabular}{|c|c|c|c|c|c|c|c|c|c|c|c|c|c|}
\hline $\begin{array}{l}\text { Name of } \\
\text { aquifer }\end{array}$ & $q_{\text {topin }}$ & $q_{\text {topout }}$ & $\begin{array}{l}q_{\text {toprez }} \\
(2+3)\end{array}$ & $q_{\text {botout }}$ & $q_{\text {botin }}$ & $\begin{array}{c}q_{\text {botrez }} \\
(5+6)\end{array}$ & $\begin{array}{l}q_{\text {topinl }} \\
(2+5)\end{array}$ & $\begin{array}{l}q_{\text {topoutl }} \\
(3+6)\end{array}$ & $\begin{array}{l}q_{\text {toprezl }} \\
(4+7) \\
(8+9)\end{array}$ & rivers & lakes & boundary & wells \\
\hline 1 & 2 & 3 & 4 & 5 & 6 & 7 & 8 & 9 & 10 & 11 & 12 & 13 & 14 \\
\hline Q2 & 11194 & -3775 & 7419 & -6992 & 3461 & -3531 & 4202 & -314 & 3888 & -3288 & -426 & -118 & -56 \\
\hline Q1 & 6992 & -3461 & 3531 & -6855 & 3349 & -3506 & 137 & -112 & 25 & -7 & 0 & -18 & 0 \\
\hline D3ktl\# & 6855 & -3349 & 3506 & -6524 & 3191 & -3333 & 331 & -158 & 173 & -192 & 0 & 20 & -1 \\
\hline D3zg\# & 6524 & -3191 & 3333 & -6284 & 3014 & -3270 & 240 & -177 & 63 & -41 & 0 & -18 & -4 \\
\hline D3krs & 6284 & -3014 & 3270 & -6233 & 2986 & -3247 & 51 & -28 & 23 & -11 & 0 & -8 & -4 \\
\hline D3dg\# & 6233 & -2986 & 3247 & -4981 & 2333 & -2648 & 1252 & -653 & 599 & -569 & -10 & -15 & -5 \\
\hline D3pl & 4981 & -2333 & 2648 & -3981 & 1849 & -2132 & 1000 & -484 & 516 & -446 & 8 & -70 & -8 \\
\hline D3am & 3981 & -1849 & 2132 & -3622 & 1634 & -1988 & 359 & -215 & 144 & -93 & 0 & -50 & -1 \\
\hline D3gj2 & 3622 & -1634 & 1988 & -3041 & 1418 & -1623 & 581 & -216 & 365 & -244 & 0 & -96 & -25 \\
\hline D3gj1 & 3041 & -1418 & 1623 & -2114 & 996 & -1118 & 927 & -422 & 505 & -327 & 0 & -154 & -24 \\
\hline D2brt & 2114 & -996 & 1118 & -852 & 423 & -429 & 1262 & -573 & 689 & -462 & 0 & -214 & -13 \\
\hline D2ar & 852 & -423 & 429 & -256 & 36 & -220 & 596 & -387 & 209 & 0 & 0 & -195 & -14 \\
\hline Model & 11194 & -3775 & 7419 & -256 & 36 & -220 & 10938 & -3739 & 7199 & -5680 & -428 & -936 & -155 \\
\hline $\mathrm{Q} 1+\mathrm{Q} 2$ & 11194 & -3775 & 7419 & -6855 & 3349 & -3506 & 4339 & -426 & 3913 & -3295 & -426 & -136 & -56 \\
\hline Primary & 6855 & -3349 & 3506 & -256 & 36 & -220 & 6599 & -3313 & 3286 & -2385 & -2 & -800 & -99 \\
\hline
\end{tabular}

LAMO3

\begin{tabular}{|l|l|l|l|l|l|l|l|l|l|l|l|l|l|}
\hline $\begin{array}{c}\text { Name of } \\
\text { aquifer }\end{array}$ & $q_{\text {topin }}$ & $q_{\text {topout }}$ & $\begin{array}{c}q_{\text {toprez }} \\
(2+3)\end{array}$ & $q_{\text {botout }}$ & $q_{\text {botin }}$ & $\begin{array}{c}q_{\text {botrez }} \\
(5+6)\end{array}$ & $\begin{array}{l}q_{\text {topinl }} \\
(2+5)\end{array}$ & $\begin{array}{l}q_{\text {topoutl }} \\
(3+6)\end{array}$ & $\begin{array}{c}q_{\text {toprezl }} \\
(4+7) \\
(8+9)\end{array}$ & rivers & lakes & boundary & wells \\
\hline 1 & 2 & 3 & 4 & 5 & 6 & 7 & 8 & 9 & 10 & 11 & 12 & 13 & 14 \\
\hline Q2 & 12762 & -1804 & 10958 & -7125 & 3390 & -3735 & 5637 & 1586 & 7223 & -6596 & -487 & -84 & -56 \\
\hline Q1\# & 7125 & -3390 & 3735 & -6960 & 3272 & -3688 & 165 & -118 & 47 & -31 & 0 & -16 & 0 \\
\hline D3ktl\# & 6960 & -3272 & 3688 & -6593 & 3166 & -3427 & 367 & -106 & 261 & -277 & 0 & 17 & -1 \\
\hline D3zg\# & 6593 & -3166 & 3427 & -6205 & 2860 & -3345 & 388 & -306 & 82 & -64 & -3 & -11 & -4 \\
\hline D3krs & 6205 & -2860 & 3345 & -6027 & 2776 & -3251 & 178 & -84 & 94 & -80 & 0 & -10 & -4 \\
\hline D3dg\# & 6027 & -2776 & 3251 & -4588 & 2137 & -2451 & 1439 & -639 & 800 & -692 & -90 & -13 & -5 \\
\hline D3pl & 4588 & -2137 & 2451 & -3279 & 1302 & -1977 & 1309 & -835 & 474 & -361 & -8 & -60 & -45 \\
\hline D3am & 3279 & -1302 & 1977 & -2872 & 1157 & -1715 & 407 & -145 & 262 & -237 & 0 & -24 & -1 \\
\hline D3gj2 & 2872 & -1157 & 1715 & -2184 & 996 & -1188 & 688 & -161 & 527 & -443 & 0 & -59 & -25 \\
\hline D3gj1 & 2184 & -996 & 1188 & -1554 & 688 & -866 & 630 & -308 & 322 & -213 & -5 & -80 & -24 \\
\hline D2brt & 1554 & -688 & 866 & -596 & 287 & -309 & 958 & -401 & 557 & -442 & -6 & -96 & -13 \\
\hline D2ar & 596 & -287 & 309 & -229 & 34 & -195 & 367 & -253 & 114 & 0 & 0 & -100 & -14 \\
\hline Model & 12762 & -1804 & 10958 & -229 & 34 & -195 & 12533 & -1770 & 10763 & -9436 & -599 & -536 & -192 \\
\hline Q1+Q2 & 12762 & -1804 & 10958 & -6960 & 3272 & -3688 & 5802 & 1468 & 7270 & -6627 & -487 & -100 & -56 \\
\hline Primary & 6960 & -3272 & 3688 & -229 & 34 & -195 & 6731 & -3238 & 3493 & -2809 & -112 & -436 & -136 \\
\hline
\end{tabular}

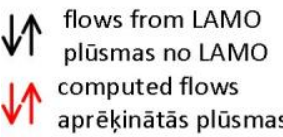

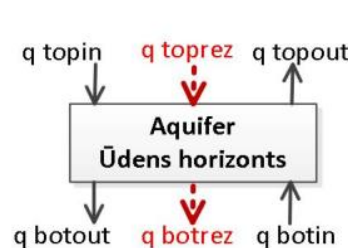

a)

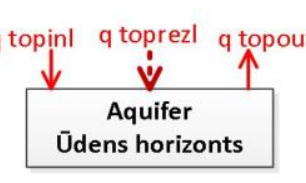

b)

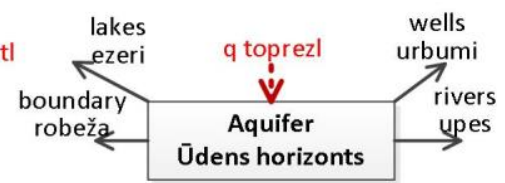

c)

Legend of stages a), b), c) for obtaining the flow of Table IIA:

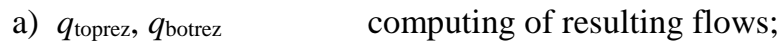

b) $q_{\text {topinl }}, q_{\text {topoutl }}, q_{\text {toprezl }}$ computing of local flows;

c) local balance of aquifer 
TABLE IIIA

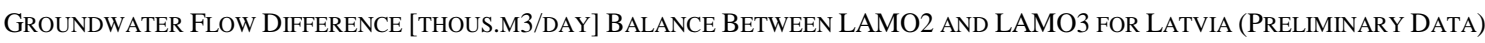

\begin{tabular}{|c|c|c|c|c|c|c|c|c|c|c|c|c|c|}
\hline $\begin{array}{l}\text { Name of } \\
\text { aquifer }\end{array}$ & $\Delta q_{\text {topin }}$ & $\Delta q_{\text {topout }}$ & $\begin{array}{c}\Delta q_{\text {toprez }} \\
(2+3)\end{array}$ & $\Delta q_{\text {botout }}$ & $\Delta q_{\text {botin }}$ & $\begin{array}{c}q_{\text {botrez }} \\
(5+6)\end{array}$ & $\begin{array}{l}\Delta q_{\text {topinl }} \\
(2+5)\end{array}$ & $\begin{array}{c}\Delta q_{\text {topoutl }} \\
(3+6)\end{array}$ & $\begin{array}{c}\Delta q_{\text {toprezl }} \\
(4+7) \\
(8+9)\end{array}$ & $\Delta$ rivers & $\Delta$ lakes & $\Delta$ boundary & $\Delta$ wells \\
\hline 1 & 2 & 3 & 4 & 5 & 6 & 7 & 8 & 9 & 10 & 11 & 12 & 13 & 14 \\
\hline Q2 & 1568 & 1971 & 3539 & -133 & -71 & -204 & 1435 & 1900 & 3335 & 3308 & 61 & -34 & 0 \\
\hline Q1\# & 133 & 71 & 204 & -105 & $\begin{array}{l}-77 \\
\end{array}$ & $\begin{array}{l}-182 \\
\end{array}$ & 28 & -6 & 22 & 24 & 0 & -2 & 0 \\
\hline D3ktl\# & 105 & 77 & 182 & -69 & -25 & -94 & 36 & 52 & 88 & 85 & 0 & 3 & 0 \\
\hline D3zg\# & 69 & 25 & 94 & 79 & -154 & -75 & 148 & -129 & 19 & 23 & 3 & -7 & 0 \\
\hline D3krs & -79 & 154 & 75 & 206 & -210 & -4 & 127 & -56 & 71 & 69 & 0 & 2 & 0 \\
\hline D3dg\# & -206 & 216 & 4 & 393 & -196 & 197 & 187 & 14 & 201 & 123 & 80 & -2 & 0 \\
\hline D3pl & $\begin{array}{l}-393 \\
\end{array}$ & 196 & $\begin{array}{l}-197 \\
\end{array}$ & 702 & $\begin{array}{l}-547 \\
\end{array}$ & 155 & 309 & -351 & -42 & -85 & 16 & -10 & 37 \\
\hline D3am & -702 & 547 & -155 & 750 & -477 & 273 & 48 & 70 & 118 & 144 & 0 & -26 & 0 \\
\hline D3gj2 & -750 & 477 & $\begin{array}{l}-273 \\
\end{array}$ & 857 & -422 & 435 & 107 & 55 & 162 & 199 & 0 & -37 & 0 \\
\hline D3gj1 & -857 & 422 & -435 & 560 & -308 & 252 & -297 & 114 & \begin{tabular}{|l|}
-183 \\
\end{tabular} & -114 & 5 & -74 & 0 \\
\hline D2brt & -560 & 308 & -252 & 256 & -136 & 120 & -304 & 172 & -132 & -20 & 6 & -118 & 0 \\
\hline D2ar & -256 & 136 & -120 & 27 & $\begin{array}{l}-2 \\
\end{array}$ & 25 & -229 & 134 & -95 & 0 & 0 & -95 & 0 \\
\hline Model & 1568 & 1971 & 3539 & 27 & -2 & 25 & 1595 & 1969 & 3564 & 3756 & 171 & -400 & 37 \\
\hline $\mathrm{Q} 1+\mathrm{Q} 2$ & 1568 & 1971 & 3539 & -105 & -77 & -182 & 1463 & 1894 & 3357 & 3332 & 61 & -36 & 0 \\
\hline Primary & 105 & 77 & 182 & 27 & -2 & 25 & 132 & 75 & 207 & 424 & 110 & -364 & 37 \\
\hline
\end{tabular}

Contents of Table IIIA are difference $\Delta=q_{\text {LAMO3- }} q_{\text {LAMO2 }}$ between contents of Table IIa for LAMO3 and LAMO2.

TABLE IVA

GROUNDWATER Flow RELATIVE DifFERENCE [\%] BETWEen LOCAL BALANCES OF LAMO2 AND LAMO3

\begin{tabular}{|l|c|c|c|c|c|}
\hline Name of aquifer & $\delta_{\text {toprez }}$ & $\delta_{\text {river }}$ & $\delta_{\text {lakes }}$ & $\delta_{\text {border }}$ & $\delta_{\text {wells }}$ \\
\hline 1 & 2 & 3 & 4 & 5 & 6 \\
\hline Q2 & 85 & 100 & 14 & -29 & 0 \\
\hline Q1\# & 88 & 243 & 0 & -10 & 0 \\
\hline D3ktl\# & 51 & 44 & 0 & 15 & 0 \\
\hline D3zg\# & 11 & 12 & $\infty$ & -39 & 0 \\
\hline D3krs & 308 & 627 & 0 & 25 & 0 \\
\hline D3dg\# & 33 & 21 & 800 & -13 & 0 \\
\hline D3pl & -8 & -19 & 200 & -14 & 462 \\
\hline D3am & 82 & 155 & 0 & -52 & 0 \\
\hline D3gj2 & 44 & 81 & 0 & -38 & 0 \\
\hline D3gj1 & -36 & -35 & $\infty$ & -48 & 0 \\
\hline D2brt & -19 & -4 & $\infty$ & -55 & 0 \\
\hline D2ar & -45 & 0 & 0 & -49 & 22 \\
\hline Model & 2 & 66 & 40 & -47 & 0 \\
\hline Q1+Q2 & 96 & 101 & 14 & -26 & -45 \\
\hline Primary & 6 & 18 & 550 & & \\
\hline
\end{tabular}

Contents of Table IVA are relative difference $\delta=100 \Delta / q_{\text {LAMO2 }}$ that are computed as division of Table IIA / Table IIA (LAMO2) 


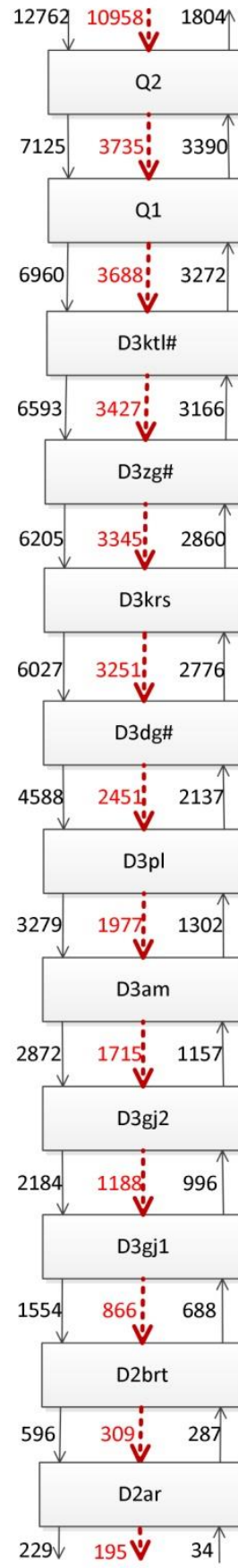

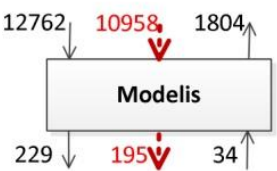

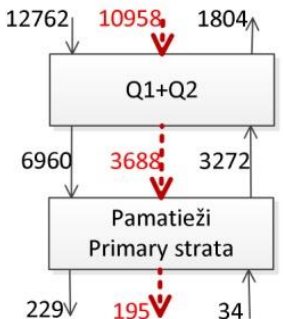

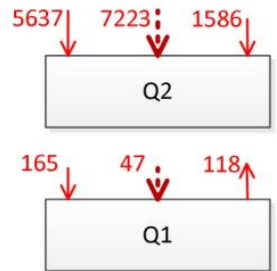
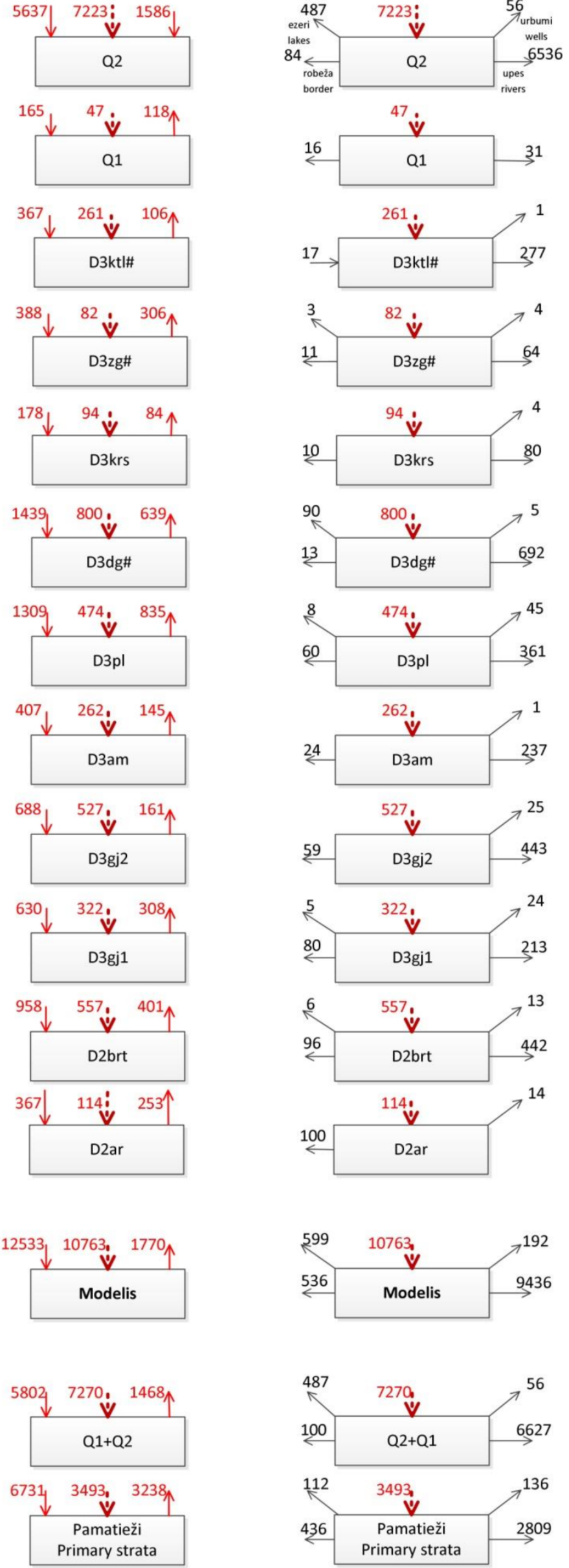

Fig. 6a. Scheme of LAMO3 groundwater flow balance of Latvia for Table IIa. 

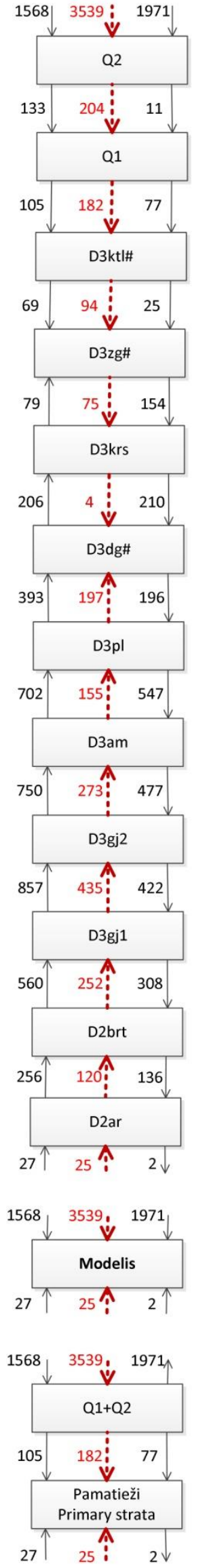
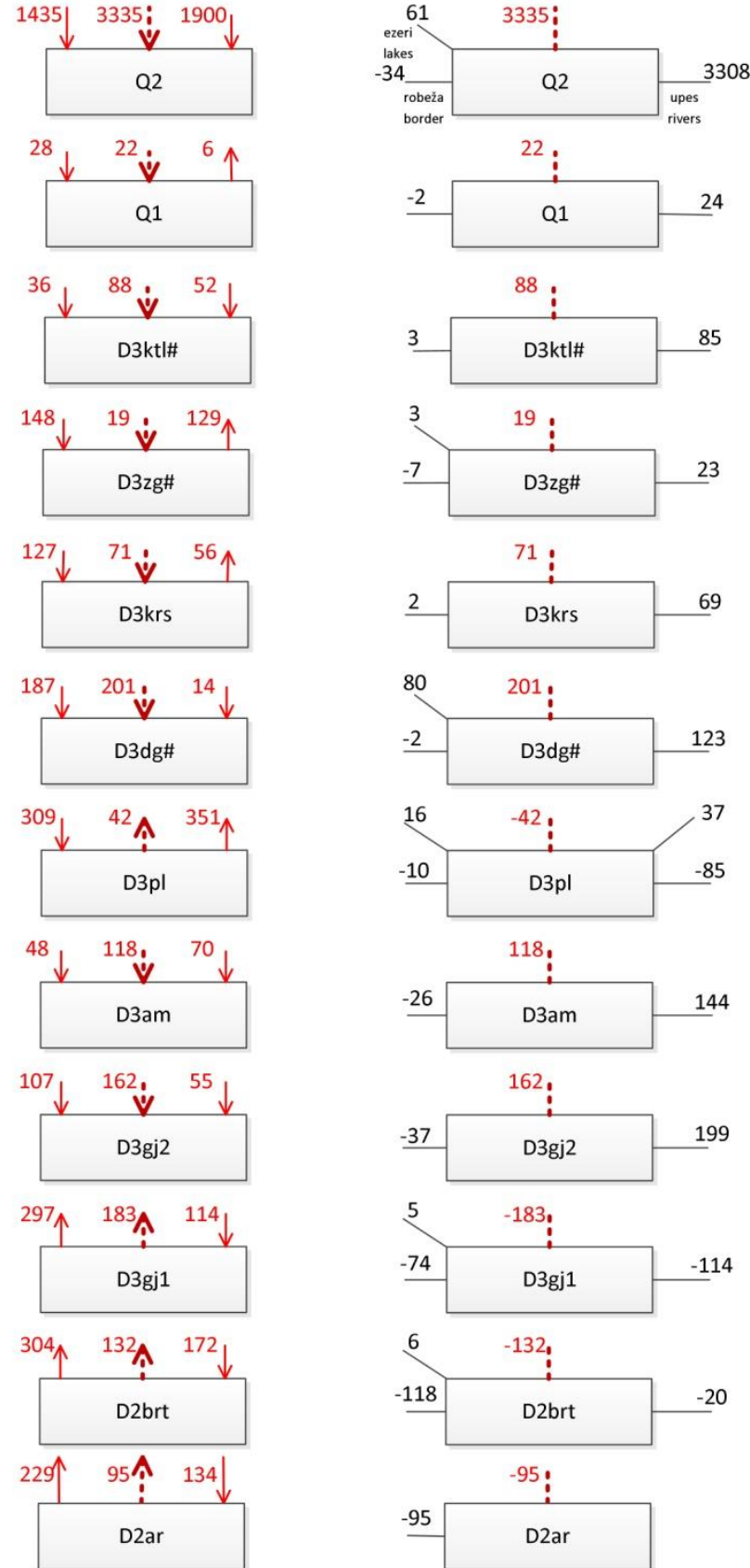

88

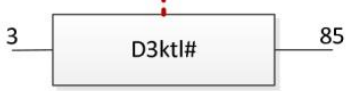

319 :
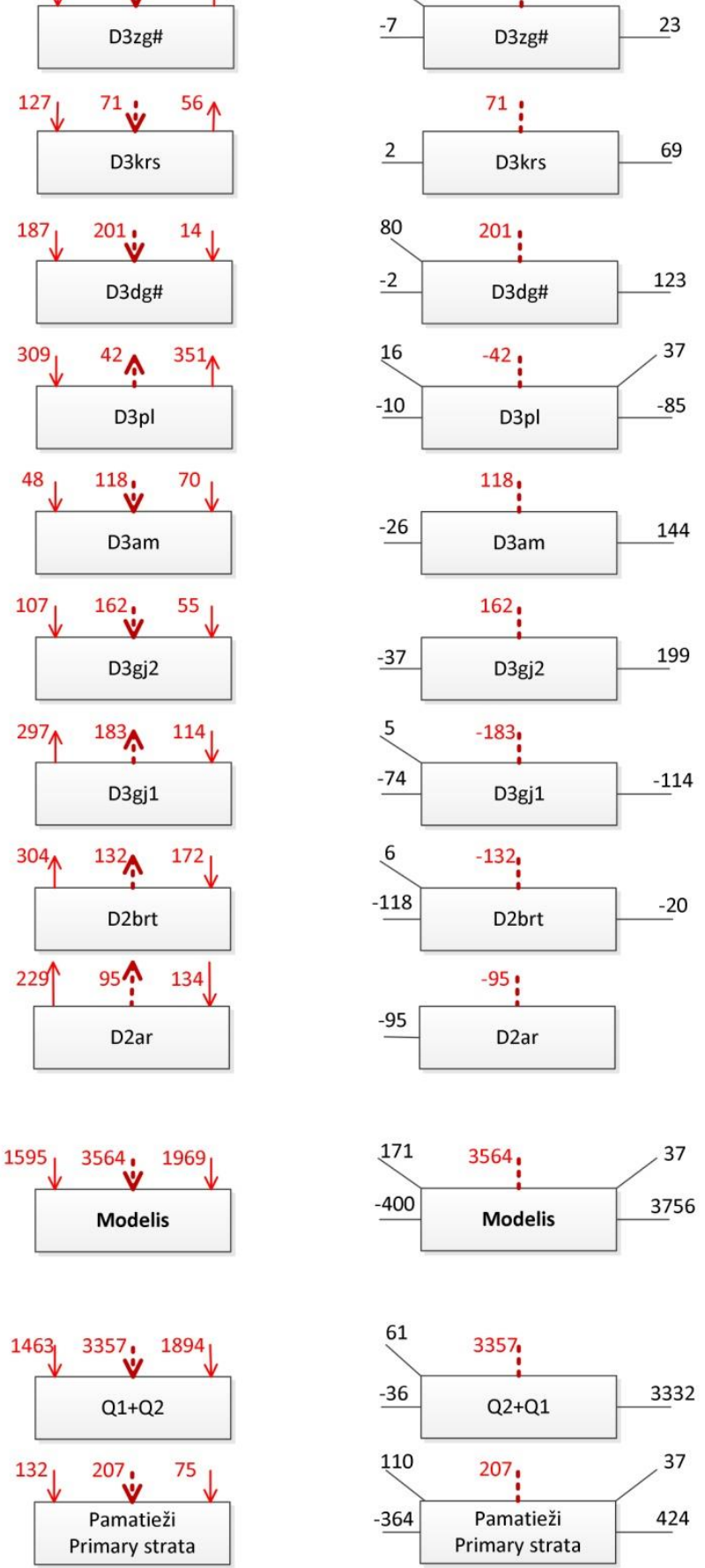

Fig. 7a. Scheme of LAMO2 and LAMO3 groundwater flow difference balance for Table IIIa. 


\section{REFERENCES}

[1] "Water Framework Directive (2000/60/EC of the European Parliamen and of the Council), Official Journal of the European Communities" L327, 22.12.2000, 2000.

[2] A. Spalvins, J. Slangens, K. Krauklis, I. Lace, and O. Aleksans, "Novel methods used to develop hydrogeological model of Latvia," in Proceedings of 27-th European Conference on Modelling and Simulation ECMS, 2013, p. 136-143.

[3] "Environmental Simulations, Inc. Groundwater Vistas - 6, Guide to using,"2011, [Online]. Available: http://www.groundwatersoftware.com/ groundwater_vistas.htm [Accessed May 15, 2014].

[4] "Golden Software, SURFER - 9 for Windows, Users Manual," 2010 , [Online]. Available: http://www.goldensoftware.com/products/surfer [Accessed May 20, 2014].

[5] J. Walkenbach, Excel $2007 \mathrm{Bibl}$, Indianapolis, Indiana: Wiley Publishing, Inc., 2007.

[6] A. Spalvins, J. Slangens, K. Krauklis, and I. Lace, "Methods and tools to be applied for creating of regional hydrogeological model of Latvia," in 25th European Conference on Modelling and Simulation, 2011, pp. 132-141.

[7] A. Spalvins, J. Slangens, O. Aleksans, K. Krauklis, and I. Lace, "Regional hydrogeological model of Latvia for management of its groundwater resources," in 5-th International scientific conference Applied information and communication technologies, 2012, pp. 135-155.

[8] A. Spalvins, J. Slangens, I. Lace, and K. Krauklis, "Geological profiles as efficient means for expounding results provided by hydrogeological model of Latvia," in 14th Geo Conference on Science and Technologies in Geology, Exploration and Mining (SGEM), Conference Proceedings, vol. II, 2012, pp. 401-408.

[9] A. Spalvins, J. Slangens, I. Lace, K. Krauklis, and O. Aleksans, "Efficient Methods Used to Create Hydrogeological Model of Latvia," International Review on Modelling and Simulations, (I.RE.MO.S), vol. 6, no. 5, pp. 1718-1726, Okt. 2013.

10] "Mapping of groundwater bodies of the Gauja-Koiva river basin district," Report on contract carried out by Riga Technical University, 25-maps (in Latvian), 2013. [Online]. Available: http://www.emc.rtu.lv/. [Accessed May 20, 2014].

[11] "Mapping for the Gauja river basin district by using results of hydrogeological model of Latvia," Riga Technical University, 12 p., 49 maps, 6 tables, (in Latvian), 2013. [Online]. Available: http://www.emc.rtu.lv/, [Accessed May 20, 2014].

[12] "Mapping for the Daugava river basin district by using results of hydrogeological model of Latvia," Riga Technical University, 12 p., 52 maps, 7 tables, (in Latvian), 2013. [Online]. Available: http://www.emc.rtu.lv/. [Accessed May 20, 2014]

[13] "Mapping for the Lielupe river basin district by using results of hydrogeological model of Latvia," Riga Technical University, 12 p., 55 maps, 7 tables, (in Latvian), 2013. [Online]. Available: http://www.emc.rtu.lv/. [Accessed May 20, 2014].

[14] "Mapping for the Venta river basin district by using results of hydrogeological model of Latvia," Riga technical University, 12 p., 57 maps, 7 tables, (in Latvian), 2013. [Online]. Available: http://www.emc.rtu.lv/. [Accessed May 20, 2014].

[15] A. Spalvins, J. Slangens, I. Lace, K. Krauklis, and O. Aleksans, "Survey of the first results provided by hydrogeological model of Latvia," in 9-th International Conference Environmental Engineering, 2014

[16] A. Spalvins, and I. Lace, "Appliance of Pumping Data of Wells for Obtaining Transmissivity Distributions of Aquifers for Hydrogeological Model of Latvia," Scientific Journal of Riga Technical University, Boundary Field Problems and Computer Simulation, vol. 53, pp. 43-49, 2014.

[17] K. Krauklis, and J. Slangens, "Special software used for implementing elements of hydrographical network into hydrogeological model of Latvia," Scientific Journal of Riga Technical University, Boundary Field Problems and Computer Simulation, vol. 53, pp. 25-29, 2014.

[18] I. Dzilna, Resources, composition and dynamics of groundwater for the middle part of the Baltic area. Riga: Zinatne, 1970 (in Russian).

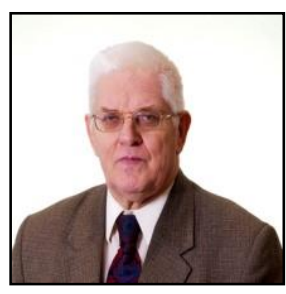

Aivars Spalvins was born in Latvia. In 1963, he graduated from Riga Polytechnical Institute (Riga Technical University since 1990) as a Computer Engineer. He is Head of the Environment Modeling Center of RTU. His research interests include computer modeling of groundwater flows and migration of contaminants.

E-mail: emc@cs.rtu.lv

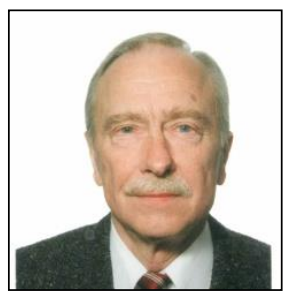

Janis Slangens was born in Latvia. In 1969, he graduated from Riga Polytechnical Institute (Riga Technical University, since 1990) as a Computer Engineer. He is a Senior Researcher with the Environment Modeling Center of RTU. His research interests include computer modeling of groundwater flows.

E-mail: emc@cs.rtu.lv

Inta Lace was born in Latvia. In 1971, she

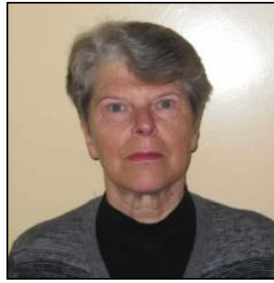
graduated from Riga Polytechnical Institute (Riga Technical University, since 1990) as a Computer Engineer. In 1995, she received the Master's degree in Applied Computer Science. Since 1991, she has been a Researcher with the Environment Modeling Center, Faculty of Computer Science and Information Technology, RTU.

E-mail: emc@cs.rtu.1v

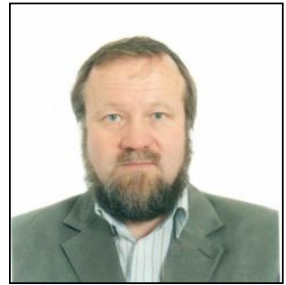

Olgerts Aleksans was born in Latvia. In 1979, he graduated from Vilnius State University as a Hydrogeologist \& Engineering Geologist. In 2011, he received the Doctor's degree in Geology. Since 2011, he is a Researcher with the Environment Modeling Center of Riga Technical University.

E-mailemc@cs.rtu.lv

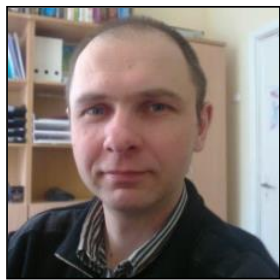

Kaspars Krauklis received a Master's Degree in Computer Systems from Riga Technical University in2007 and the Certificate in Teaching of Engineering Sciences from the Institute of Humanities of RTU in 2005. Presently he is a Researcher with the Environment Modeling Center of Riga Technical University.

E-mail: emc@cs.rtu.lv

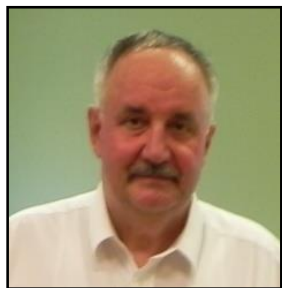

Viesturs Skibelis was born in 1945 in Germany. In 1967, he graduated from Riga Polytechnical Institute (Riga Technical University, since 1990) as a Computer Engineer. In 2001, he received the Master's degree in Applied Computer Science. He is a Researcher with the Environment Modeling Center, Riga Technical University.

E-mail: Viesturs.Skibelis@cs.rtu.lv

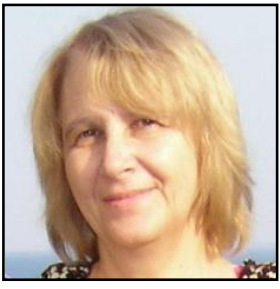

Irina Eglite received the Master's degree in Mathematics from the University of Latvia and the Master's degree in Applied Computer Science from Riga Technical University. Presently she is a $\mathrm{PhD}$ student with Riga Technical University, a Researcher with the Environment Modeling Center and a Lecturer with the Department of Engineering Mathematics, RTU

E-mail: Irina.Eglite@rtu.lv 